when three papers were read. The first, by Mr. J. Brown, F.R.S., and Prof. Maurice Fitzgerald, described a series of experiments they had carried out on rotating discs. The discs were rubber-one solid, 12 inches in diameter, with its thickness tapering from $2 \frac{1}{2}$ inches in the middle to $\frac{1}{2}$ inch at the edge, and the second 12 inches in diameter, $\frac{3}{8}$-inch thick at the edge, and 3 inches thick in the middle, where it was pierced with a $1 \frac{1}{2}$-inch hole. In the first disc the thickness varied uniformly from the centre to the edge; in the second the cross-section of the disc formed a hyperbolic curve. The object of these experiments was to determine, by measurement of the strains set up when the discs were rotating, whether the formula usually employed in the calculation of stresses in the revolving discs of steam turbines were reasonably trustworthy. The discs were carried at the lower end of a vertical shaft, which was driven at a high speed by an electric motor; photographs were taken of the revolving disc, and strain measurements were thus possible. As a result of their experiments, the authors were of opinion that the ordinary formulæ did not give results which were approximate enough for ordinary use. Of course it is well known that these formuke are only approximate, but it is doubtful whether the experiments of the authors are sufficiently conclusive to prove that the formula are as untrustworthy as was suggested in the paper.

The next paper was by Mr. Douglas Fox, on general urban and interurban transportation and rail-less electric traction. This paper contained, in the form of tables, an exhaustive analysis of the costs, working expenses, receipts, \&c., of some seventy-one tramway installations in the United Kingdom. The examples selected by the author embraced towns having combined generating stations for traction and electric lighting, and towns which had separate generating stations for their tramways and their lighting. Details were also given of several installations of electric road traction on the Continent, where overhead wires were employed and there were no rails; one of the latest of these was at Mulhausen, in Alsace, where it had been decided to adopt rail-less electric cars in order to connect up the suburbs with the existing electric tramways in the city proper. Mr. Fox was of opinion that in many of the municipal tramways ordinary business principles had been neglected and that the public had been allowed to travel at the expense of the ratepayer, fares being too low to allow, after working expenses had been defrayed, of the setting aside of a reasonable sum for depreciation and renewal.

The section concluded its proceedings with a paper on the strength of solid cylindrical, round-ended columns, by Prof. W. E. Lilly. In previous papers by this author the importance of secondary flexure and its influence on the strength of columns had been demonstrated, and as a result of his researches he had suggested the revision of the formula at present in use for the design of columns. The modified formula which the author had suggested required certain constants, and the object of the experiments described in the present paper was the determination of the value of these constants. Experiments had been carried out on columns of cast tool steel, Bessemer steel, mild steel, wrought-iron, and cast-iron, and the results obtained were given by the author in the form of a table: the constants in this table were for use with the well-known Rankine Gordon formula.

\section{AGRICULTURE AT THE BRITISH ASSOCIATION}

THE Dublin meeting of the British Association was marked by the resuscitation of the subsection of agriculture, which, after a previous temporary existence as a dependent of botany and some fitful appearances as a branch of chemistry, now became associated with economics. As was appropriate in these circumstances, and with Sir Horace Plunkett as president, the work of the subsertion was mainly concerned with the economic, or rsther with the sociological, side of agriculture.

Thursday morning was occupied with the presidential address, in which, at the outset, Sir Horace said that he No. 2034 , VOL. 78$]$ spoke neither as a man of science nor as a practical farmer, but as a man of affairs whose way of life had brought him into close touch with the conditions, human and material, which it will be the aim of the subsection to improve. His purpose was to establish the claim of agriculture to a new position in the domain of science, for reasons that are primarily neither scientific nor practical, but political. It does not appear to have been sufficiently considered how far the ethical and physical health of the modern city has been due to the constant influx of fresh blood from the country. At present the town makes an irresistible appeal to the spirit of enterprise, to the growing craving for excitement, to the desire to live where there is most life. But sooner or later, if the balance of trade in this human traffic be not adjusted, the raw material out of which urban society is made will be seriously deteriorated, and the national degeneracy will be properly charged to those who failed to foresee the evil and treat the cause. If the problem has not yet received the proper attention at the hands of the sciences, its urgency is growing in the public opinion and stirring the centres of government. The influence of the British Association upon national life must depend, not upon its highest achievements in the region of pure science, but upon the degree in which it establishes and maintains a mutually helpful relationship between science and productive effort. He did not suggest that agriculture had not shared in the benefits with which science, physical and social, had richly endowed the whole field of industrial effort, urban and rural. But there is surely a marked disparity between the attention given to urban and rural affairs by those engaged in the application of science to the advancement of mankind. A great gulf, no doubt, separates the agriculture of Vergil from that of Sir John Lawes, but how insignificant it is beside the ocean of knowledge which stretches between Archimedes and Lord Kelvin. In his work in Ireland he had been in the habit of employing a rough formula to indicate the three-fold character of the constructive work that is needed in rural life-better farming, better business, and better living. To each of these three divisions the sciences ought to be most helpful; the natural sciences to the first, economic science to the second and third, educational science to all three. Sir Horace then proceeded to emphasise in greater detail the necessary part played by research, by economic investigation, and by education in rural reconstruction. Lastly, he proceeded to plead for the more adequate recognition of agriculture by the association; he demanded that it should be accorded the dignity of a section instead of being left in its present unstable condition, without any organisation to secure the continuity of even a subsection from year to year. The association might thus help to " counteract tendencies through which preceding empires, after they had arrived at a stage very similar to that which we occupy to-day, hastened to their decline and fall. Be this as it may, it would hardly be an exaggeration to say that modern civilisation has joined the rural exodus. Let it be the high aim of the British Association, leading science and practice hand in hand, to call it back."

In the afternoon following the presidential address, Sir Oliver Lodge described some of the experiments, which are being made on a large scale near Worcester, on the effects of a high-tension electrical discharge over a growing crop. While carefully guarding himself from any speculation as to whether the seat of the action was in the soi] or the plant, whether a stimulus action or an inflow of energy, there seemed to be a positive result which was quite outside the domain of experimental error. $\mathrm{Mr}$. J. H. Priestley, who has been associated with the experiments, gave some further details, and explained the investigations he had in hand to elucidate the nature of the action of the electricity. Then followed a paper by Prof. J. R. Campbell, of the Irish Department of Agriculture, in which he lucidly explained the educational work of that department, where the following of a carefully considered policy has achieved much happier results than the wasteful English method of leaving each county council to go as it pleases. Education was also the text of the next paper, by Dr. Carroll Dunham, of Harvard, in which he compared the systems of agricultural education prevailing in the United States, according as their aim was to prepare 
the students for business as farmers or for teaching and research.

Two more purely scientific papers were also taken on the first day; Dr. G. H. Carpenter described some of his work upon the warble-tly and its attacks, and Mr. H. Hunter explained the results of the long and systematic trials of barley varieties that have been made in Ireland by the cooperation of Messrs. Guinness with the Department of Agriculture. These trials have established beyond any doubt the general superiority of "Archer" to other barleys, both from the farmers' and the brewers' standpoint, thus confirming the results of the very similar trials made in Denmark.

Friday was given over to papers and discussions on breeding and on the light which science is beginning to throw on the problems of the stock raiser. Mr. Bateson opened the proceedings by a luminous exposition of the Mendelian standpoint, with illustrations of how the work of the raise of new varieties of plants or the improver of breeds of animals could reduce his work to something like certainty, and work by design instead of by chance. Mr. W. Heape, F.R.S., who followed, pleaded for the establishment of experimental farms devoted to the solution of breeding problems; attention is at present exclusively given to the raising of crops, forgetting the enormous importance of our live-stock business. To Ireland such experimental work would be specially valuable. Mr. Punnett then gave an account of some of the more special applications of the Mendelian principles to stock questions, and Prof. J. Wilson showed how the facts of colour inheritance in cattle led to certain conclusions concerning the original races of cattle which have gone to make up the breeds now prevailing in the British Islands.

On the Monday the section resumed its previous economic point of view, and gave itielf up to a very animated discussion of the factors which make for the success of small holdings. Mrs. Wilkins (Miss Jebb) opened the proceedings with a paper in which she sketched the very various conditions under which success had been achieved in England, and the necessity of certain collateral developments, such as cooperation, if any considerable numbers of small holders have to support themselves upon the land. She maintained that the fact that small tradespeople and mechanics rather than agricultural labourers are at the present moment chiefly applying for small holdings is really a good omen for the success of the movement, since such men are, as a rule, better able to make an economic use of the land than men who would be forced to depend wholly upon their small farming.

Mr. Christopher Turnor insisted on the importance of guiding the small holder in his methods of work and cropping, even to the extent of establishing in each district one or two model holdings cultivated for demonstration purposes. Mr. F. Impey gave some account of the work that had been done in Great Britain in obtaining small holdings of recent years, and Mr. Beach Thomas described the evidence he had received as to the widespread desire of city workers to get back to the land. An animated discussion followed, a little political, perhaps, at times, and not wholly devoid of rhetorical heat, but still informing; the general impression which seemed to emerge was that success is being attained by market gardening and fruit growing rather than by small farming. The president showed that in many cases, especially in Ireland, it is the community rather than the individual who should be the small holder, thus automatically ensuring cooperation both in the work and the trading.

The last meeting was held jointly with the parent section of economics to hear various papers of a more seneral economic character. Dr. Graham Brooks discussed the moral effects of cooperation upon the workers, and Dr. Moritz Bonn, of Munich, examined the statistics relative to Irish agriculture to ascertain if the last twenty years of land reform had begun to effect any improvement in the productive power of the Irish occupier. Statistically he could detect but little change, a view for which ho was somewhat fiercely taken to task by the politicians present. Statistical papers by Prof. J. Wilson and $\mathrm{Mr}$. W. G. Adams terminated a very successful session of the subsection, at which the interest and attendance had been maintained from the first day until the last.

NO. 2034, VOL. 78 ]
METEOROLOGY IN AUSTRALIA.'

[HE Commonwealth Bureau of Meteorology, Australiu has now been in existence more than a year, and issued its first Bulletin a few months ago. This is an article on the "Climate and Meteorology of Australia," and is written by the Commonwealth meteorologist, Mr. H. $\Lambda$. Hunt. It contains some very interesting data with regard to the climate of the various capitals, and indicates that Adelaide is the driest and sunniest, and that Brisbane is the hottest, capital. The hottest region is in the northern part of West Australia, near the Marble Bar and Nullagine goldfields, where the maximum shade temperature often exceeds $100^{\circ}$ for days and even weeks continuously.

The Northern Territory and Queensland receive their rain in the summer from the monsoonal depressions from the north-east. The southern parts of West Australia and South Australia benefit from the Antarctic depressions in winter. In Victoria and Tasmania the seasonal change of rainfall is not strongly marked. New South Wales gets most of its rain in the later summer and autumn.

The wettest place is Geraldton, in north-east Queensland, with an average yearly fall of 145 inches; the driest region is round Lake Eyre, where 10 inches in one year is exceptional, 5 inches being the average.

In discussing cyclones and storms, mention is made of the "Willy Willies" which afflict the north-west parts of West Australia. These are severe cyclones which apparently originate in the Cambridge Gulf and travel south-west and south along the line of the coast, or they cross the continent towards the Australian Bight. These storms cause great havoc, and are marked by torrential rains.

The "Southerly Burster" is peculiar to the eastern parts of Australia, and is a cold wind which always follows a period of hot weather. It is usually associated with the V-shaped depression between two anticyclones. These storms are usually first noted on the extreme south coast, and they travel northward at the rate of about twenty miles per hour. The velocity of the winds varies, sometimes reaching eighty miles per hour.

Winds of similar character to "Bursters" are the "Bora" on the east coast of the Adriatic, the "Mistral" in France, the "Northers" of Texas, and the "Pampero" in the Argentine. South Africa also has a wind of like nature and origin.

\section{UNIVERSITY AND EDUCATIONAL INTE LLIGENCE.}

CAMBRIDGe.-On the occasion of the visit of the members of the International Conference on Electrical Units, the Public Orator (Dr. Sandys) spoke as follows in presenting on October I7 the several distinguished recipients of the degree of Doctor of Science honoris causa :-

(I) Scandinaviam hodie nobis quasi praesentem reddit Upsalae et Holmiae alumnus insignis, qui " electrolysis" (ut aiunt) praesertim in provincia investigatorum omnium dux et signifer merito existimatur; qui scientiae chemicae in regione physica inter conditores praecipuos numeratur; qui e scientia illa praemium orbi terrarum toti propositum reportavit, cuius laudis inter participes illustres et Cancellarium nostrum et rei physicae Professorem nostrum esse gloriamur. Idem solis ipsius naturae inter explorarores patientissimus, tempestatum inter augures perspicacissimus, (ut Aristophanis verbis paullulum mutatis

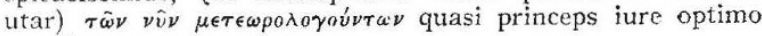
esse fertur.

Ergo Scientiarum Doctor hodie merito creatur scientiac chemicae in provincia physica Instituti Nobilis Scientiarum in Academia Regia Holmensi Rector, Svanruus Augustus ARRHENIUS.

(2) Francogallorum respublica maxima, nobis vicina, nobis amicitiae vinculis indies artioribus coniuncta, vir desideratissimi in vicem, successorem eius misit dignissimum, qui non modo inter Germanos sed etiam inter Francogallos educatus, Parisiensium in Universitate iam per annos duo et viginti scientiam physicam praeclare 1 "The Climate and Meteorology of Australia" (Reprinted from the "Year Bnok of the Commonwealth of Australia." Bulletin No. $x$, issted Marcl, igc8.) By H. A. Hunt. 